\title{
Teaching the Narrative Texts Using Animation Video: Raising Students' Skills on Reading Comprehension
}

\author{
Siti Munawaroh \\ Universitas Lancang Kuning, Pekanbaru, Indonesia \\ sitimunawaroh68@gmail.com
}

\section{ARTICLE HISTORY}

Received : 2019-06-13

Revised : 2019-06-15

Accepted : 2019-07-11

\section{KEYWORDS}

Narrative text

Animation video

Reading comprehension

\begin{abstract}
This study aims to answer the problem of whether animated videos improve reading skills in understanding language features, find real and detailed information, and take moral values in narrative texts in the classroom. The author uses classroom action research. The tools used to collect data are observation sheets, field notes, and tests. In cycle one to cycle three, the author uses animated videos as a medium to improve reading comprehension in understanding language features, finding real and detailed information, and taking moral values in narrative texts. The author uses animated videos with the activity of showing printed images of animated video stories and giving unknown words to improve students' ability to understand the narrative text language features. The author uses animated videos with predictive activities, confirmations, class discussions, and tests to improve students' ability to find real and detailed information. The author uses animated videos by reviewing each character and finding real and detailed information to improve students' ability to take moral values from narrative texts.
\end{abstract}

\section{Introduction}

In the process of teaching and learning English, the preparation of teacher teaching tools can help students in the implementation of teaching and learning. Also, the teaching method, which is used by teachers to deliver lessons and attract students' attention so that the learning process takes place, is a component that strongly supports the learning process Teaching is guiding students on how to learn. Teaching is regulating and creating an atmosphere that is in the environment of students so that they can carry out learning activities. The definition of teaching was also coined by Nasution (1982), and Tardhif (2004).

Nasution (1982: 8) argues that teaching activities are all class activities carried out by teachers in managing the environment well and connecting with children so that the learning process occurs. Thus the process and success of student learning will be determined by the role that the teacher brings during the teaching and learning process takes place. Tardhif (2004) defines, teaching is an act carried out by a teacher with the aim of helping or facilitating students to carry out learning activities.

In teaching activities very much has benefits both for learning activities. Among them are to convey knowledge, train mindset, increase understanding, and be creative. Further English is an international language that is required to exist in official schools in Indonesia and is still one of the subjects in the
National Examination in formal schools starting at the junior high school level. However, very concerning, many students made English as a "scary" subject. I don't know what is the main factor in this problem. Therefore, many teachers change the way to teach by thinking of methods that are liked by students using various types of media.

Learning media can clarify the presentation of messages and information to facilitate and improve learning processes and outcomes. During learning activities, the media is needed by teachers as an interaction tool for delivering information to students. And very much media that must be mastered by the teacher so that students do not feel bored in learning English, especially in the field of reading narrative texts. So, the use of media is expected to facilitate students to learn English language skills, which consist of the skills of listening, speaking, reading and writing. Students must master four language skills so that they can use English in both passive and active forms.

One of the language skills students must acquire is reading skills because it has an important role in the teaching and learning process. Related to this idea, Palani (5: 2012) Said, "Reading is an important activity in the learning process. In the movement of the community, greater importance has been given and is one of the important aspects of the functioning of humans, who are collectively involved in community regulation and exposure of knowledge so that people understand letters ". Readers need to 
collaborate with information, knowledge, experience and emotions to understand the text being read. They shape a person's personality, and they help individuals to develop the right method of thinking and to create new ideas. As a result, what is very important is that reading, in general, cannot be separated from the learning activities of students.

Animation video provides one story of narrative text with colour images, moving images, and scripts. This animated video is one of the media in reading comprehension to help increase students' attention so that they can be motivated to learn narrative texts. By watching animated videos about narrative text stories, students are interested in learning narrative texts. When students can understand narrative texts, they are expected to have a good understanding of narrative texts. Therefore, in this study, the authors applied animated videos as a medium in teaching narrative texts to improve students' reading comprehension in narrative texts. The author believes this research can be a successful and positive contribution to the process of teaching and learning English.

\subsection{Use of animated videos}

Teaching narrative texts using animated videos is an effective way. The author applies the procedure of using animated videos as a medium in presenting reading comprehension material in narrative texts. Animated videos are taken from the internet on You Tube. Video animation provides subtitles that can help students understand the story. This animated video is displayed in each cycle. Understanding of reading narrative texts, this study includes understanding language features, understanding factual information or details of stories, and drawing moral values from stories. Further, The learning process is held in the classroom with appropriate devices such as LCD projectors, laptops, supporting audio systems such as speakers. First of all, the teacher gives instructions to students and then the teacher shows an animated video. The teacher stops each part of the animated video and shows a picture of the print screen. After that, the teacher asks students to guess the characters, settings and places based on the print screen image shows. Also, the teacher gives foreign words from the subtitles.

This activity is carried out to make students understand the language features of narrative texts. In drawing moral values from animated video stories, the teacher asks students to understand each character and by giving questions from the animated video. The teacher also asks about the main ideas of the story. By finding out factual or detailed information, students can find the main idea well.
This animated video makes it easier for students to learn narrative texts. Further, this animated video describes a moving object with sound. Videos are very helpful in explaining the learning material.

\subsection{Narrative text}

Mandler \& DeForest, 1979; Stein \& Nezworski, 1978 cited in Klinger (2007: 77) states that the structure of narratives is often called "story grammar". Narratives cover various types, or genres, which can differ slightly from this basic story grammar template. These include realistic fiction, fantasy, fairy tales, fairy tales, fairy tales, mysteries, humour, historical fiction, drama, and real-life adventures. For example, fairy tales are short stories with typical story grammar but with moral additions. Readers remember stories better when arranged familiarly.

\subsection{Instructional Media}

According to Anderson quoted in Akmala (2011; 23), teaching media can be classified into three categories. They are. Media Visual They are media that can be seen. Can be in the form of images, moving images, animations or flash cards. b. Media Audio They are sound media. This means that audio media has the sound that we listen to. c. Audio-Visual Media They are media that have sound and images. Video animation is an example of audio-visual in teaching. Media capabilities are considered better and more interesting because they contain elements of the audio and visual media. To convey the message of learning, the teacher class usually uses teaching aids in the form of pictures, models, or other tools that can provide concrete experience, motivation to learn, and increase absorption or what is known as a visual aid. One of the computer learning media that has been developed is video learning. Video can be used as a model of positive behaviour and to motivate students. They are very useful for introducing topics or reviewing material. Material presentations through videos can influence students' interest in learning, especially in learning to read.

\section{Methods}

In this study, the authors used classroom action research (CAR). This research was conducted by teachers in the classroom through self-reflection to improve their performance as teachers so that student learning outcomes showed improvement. Action research is an approach to introducing problem identification, action, planning, implementation, evaluation, and reflection into teacher teaching. Johnson (1993) cited in Jones (2004: 1). Action research is a learning process that enables learning and creation of knowledge through critical reflection on experience, forming abstract concepts, and testing the implications of these concepts in new situations. The action in this study is as follows: 


\subsection{Planning}

Plans are preparation before teaching and learning activities. Activities in the planning stage are carried out by teachers and collaborators. Teachers and collaborators determine the day and date of the study, prepare lesson plans about narrative text material using audio-visual media, prepare narrative story material, prepare audio-visual media used in the classroom, plan learning techniques used in the classroom and prepare assessments for learning.

\subsection{Acting}

At this stage, the author teaches using animated videos. Teachers teach based on lesson plans that have been planned and observed by collaborators.

\subsection{Observe}

This activity is carried out during the data collection process. The process of data collection is done by observing all activities such as student attitudes in learning, classroom atmosphere, the material delivered by the teacher, interaction between teacher and students, interaction between students and students, and things that occur in process learning. To record the class situation during an activity is to use field notes and observation lists.

\subsection{Reflecting}

Reflecting is an evaluation by the teacher and collaborator on the process and results or the impact of the actions taken by the researcher. The steps in reflection are analyzed data from the observation sheet, field notes and test results to find out the improvement in reading comprehension in narrative texts by using animated videos and discussing the teaching and learning process that has been carried out and planned for the next activity.

Data collection tools are field notes, observation and test checklists. Field notes are used to observe and know the situation and activities during the teaching and learning process, such as how the teacher implements the material and student responses. An observation checklist is a form of the table consisting of actions applied by the author to watch objects carefully to pay attention to the class atmosphere

\section{Findings}

The research findings are discussed based on the results of the study. Three cycles of Classroom Action Research (CAR) are conducted to improve students' reading comprehension in narrative texts using animated videos.

The author explained in class with the first two animated videos entitled "The Peacock and the Crane" and the second with the title "The Fox and the crow". In general, the use of animated videos in teaching reading narrative texts increases students' reading skills in narrative texts. They have shown an increase in language features that are not understood, understood factual information or details and draw the moral values of narrative texts specifically discussed below:

1) The use of animated videos increases students' ability to understand the language features of narrative texts.

The researcher is showing animated video images of narrative texts enhancing students' ability to understand the narrative text and language features. By displaying a print screen image as a video representation so that the teacher easily guides students, students can easily understand the orientation, resolution, and complications parts. A print screen image was made to clarify the story and tell the event. In the classroom, activities are carried out in the first cycle to the third cycle, where the video stops after each part of the generic structure of the narrative text are displayed.

The teacher shows a print screen image of the video when the video is paused. By looking at pictures, students can easily understand the background and the character of the story. Giving foreign words from subtitles in animated videos of narrative texts increases students' ability to understand the language features of narrative texts.

To understand the language features of narrative texts, students must know words that are included in nouns, past tense, action verbs, time and place verbs in animated videos. The teacher has given words and phrases from the video, and the teacher asks students to find the narrative text language feature. The author uses animated videos with subtitles. Using video subtitles will also help language learners develop their vocabulary levels.

The meaning of vocabulary requires the reader to guess certain words or phrases from the context. When watching videos, students find several words or phrases in the sentence. This activity will make a better understanding for students. In this activity, the teacher gives words and phrases and asks students to find the language features of the narrative text correctly.

2). The use of animated videos increases students in finding out factual information or narrative text details

Predict what will happen in the animated video narrative text story increasing students in finding out information or narrative text details. To understand the event, the teacher asked several predictive questions related to the story in the narrative text video animation. The teacher asks students to see what happens in complications and resolution. 
- Confirming the orientation and events that have occurred in the animated video narrative story increase students in finding factual information or details from narrative texts. In confirming orientation and events, the teacher reviews each event that has occurred when the video is paused in orientation, complications, and resolution. The teacher asked several confirmation questions related to the story. This activity is to help students understand factual or detailed information.

- Having class discussion activities increases students in finding factual information or details from narrative texts. Through class discussion activities, students can share opinions and give ideas. This helps students to be more confident in answering questions. Students answer teacher questions based on their discussion with their spouse and group. This activity can help students to understand factual information or details. When students discuss the story, they discuss cooperatively.

- Testing activities improve students' reading comprehension in narrative texts. With testing activities, the author knows the progress of students in each cycle to understand narrative texts. In this study, the authors used the test in the form of essays at the end of each meeting to measure student learning achievement about the material.

3). The use of animated videos increases the ability of students in narrative texts to draw moral values.

Moral values are suggestions relating to character, study, or morals that can be obtained from the reader of the story being read. Students have tried to draw moral values from each cycle in the class.

- Reviewing each character in the animated video story narrative text increases students' ability in narrative texts to draw moral values. To find out the moral value of the story given, the teacher asks about the characters in the story. By remembering the character as a whole, students can easily understand moral values.

- Understanding factual information or details of the story of animated video narrative texts increases students' ability in narrative texts to draw moral values. The previous discussion about understanding factual or detailed information also helped students to draw moral values. Students and teachers make conclusions about the stories in the video. The teacher must also revise his teaching methods using animated videos.

The results showed that students tried to experience improvement from the first meeting in understanding the story.

\section{Discussions}

In this study, students showed progress in understanding narrative texts. Animated videos make it easier for students to learn narrative texts. Animated videos describe moving objects with sound. Videos are very helpful in explaining the material. During the implementation of the video, students were seen enjoying and very enthusiastic in the learning process. They pay attention to the stories. However, the limitations of this study are that not all students can learn visual media that is used well. Some students get bored when the duration of the video is long; therefore, at the next meeting, the teacher prepared a short animated video of narrative text. In addition, some students lose focus when viewing videos, so the teacher reminds students to watch and pay attention to the video.

Furthermore, there are students who want to learn in a way explained by the teacher and students who want to learn by playing and others. So, to eliminate this problem, during watching videos, students are given the task of writing creative conclusions from what they have seen and heard. The combination of watching videos with other tasks (worksheets, group discussions, asking questions) will have an impact on improving student learning outcomes because of as a human; we can remember something that has seen, heard, and done it all at once.

\section{Conclusions}

According to the discussion from the previous chapter, it can be concluded that the use of video animation in teaching narrative texts as media increases students' reading comprehension from cycle to cycle. This media not only increases students' reading comprehension in narrative texts but also motivates students to learn narrative texts in different ways.

Before using this media, students cannot understand narrative texts well. But by using this media, this helps students to understand language features, know factual or detailed information and also draw moral values from narrative texts. In addition, the use of animated videos can improve students' reading comprehension. Student reading competence increases from the first cycle to the third cycle. It is shown by the increase in student grades and the learning process carried out by teachers and collaborators fulfilling all aspects of the teaching objectives. This proves that the use of animated videos in teaching reading is very helpful, especially in improving students' reading comprehension of narrative texts. 


\section{References}

Akmala, T. A. (2011). The use of animated film to improve students' ability in writing narrative text (a classroom action research at the 10th grade of Madrasah Aliyah Negeri Pemalang in the academic year of 2010/2011) (Doctoral dissertation, IAIN Walisongo).

Ali, M., Zamzuri, A., Samsudin, K., Hassan, M., \& Sidek, S. F. (2011). Does Screencast Teaching Software Application Needs Narration for Effective Learning?. Turkish Online Journal of Educational Technology-TOJET, 10(3), 76-82.

Anom, D. (2018). The Use of Preview, Question, Read, Summarize, Test (PQRST) Strategy to Improve Students' Reading Comprehension in Recount Text. ELT-Lectura, 5(2), 117-126.

Cakir, I. (2006). The use of video as an audio-visual material in foreign language teaching classroom. Turkish Online Journal of Educational Technology-TOJET, 5(4), 67-72.

Dahler, D., Putra, R. J., Zaim, M., \& Fauzan, A. (2019, January). Using Read Cover Remember Retell (RCRR) in Teaching Reading Comprehension. In International Conference on Islamic Education (ICoIE 2018). Atlantis Press.

Hafner, C. A. (2014). Embedding digital literacies in English language teaching: Students' digital video projects as multimodal ensembles. Tesol Quarterly, 48(4), 655-685.

Jones, D., Kaufman, E., \& Rudd, R. (2004). Daily classroom improvement with action research. The Agricultural Education Magazine, 76(6), 8.

Kasriyati, D. (2016). A Study on Students' Ability in Identifying Types of Supporting Ideas in The Texts. ELT-Lectura, 3(1).

Ko, S., \& Rossen, S. (2017). Teaching online: A practical guide. Routledge.

Kuraedah, S., Gunawan, F., Wekke, I. S., \& Hamuddin, B. (2018, July). Learning Environment Construction in Islamic Higher Education: Connecting the Puzzles of Ideas. In IOP Conference Series: Earth and Environmental Science (Vol. 175, No. 1, p. 012107). IOP Publishing.

Lusandi, B., Syahdan (2018, May). Developing Maritime Thematic Expressions on English Reading Materials Used In Indonesia: Junior High School Context. In IOP Conference Series: Earth and Environmental Science (Vol. 156, No. 1, p. 012065). IOP Publishing.
Mayer, R. E. (2017). Using multimedia for e-learning. Journal of Computer Assisted Learning, 33(5), 403-423.

Mayer, R. E. (2017). Using multimedia for e-learning. Journal of Computer Assisted Learning, 33(5), 403-423.

Meyer, B. J., \& Ray, M. N. (2017). Structure strategy interventions: Increasing reading comprehension of expository text. International Electronic Journal of Elementary Education, 4(1), 127-152.

Syaifullah, S. (2014). The Use of Comic Strips in Teaching Reading A Descriptive Text at The Seventh Grade Students Of Smpn 3 Pekanbaru. Lectura: Jurnal Pendidikan, 5(1).

Tafani, V. (2009). Teaching English through Mass Media. Acta didactica napocensia, 2(1), 81-95.

Wekke, I. S., Yandra, A., \& Hamuddin, B. (2017, December). Learning Strategy in Class Management: A Reflection from Manado Case. In IOP Conference Series: Earth and Environmental Science (Vol. 97, No. 1, p. 012053). IOP Publishing. 